\title{
Missionaries and their medicine
}

A Christian modernity

for tribal India

DAVID HARDIMAN

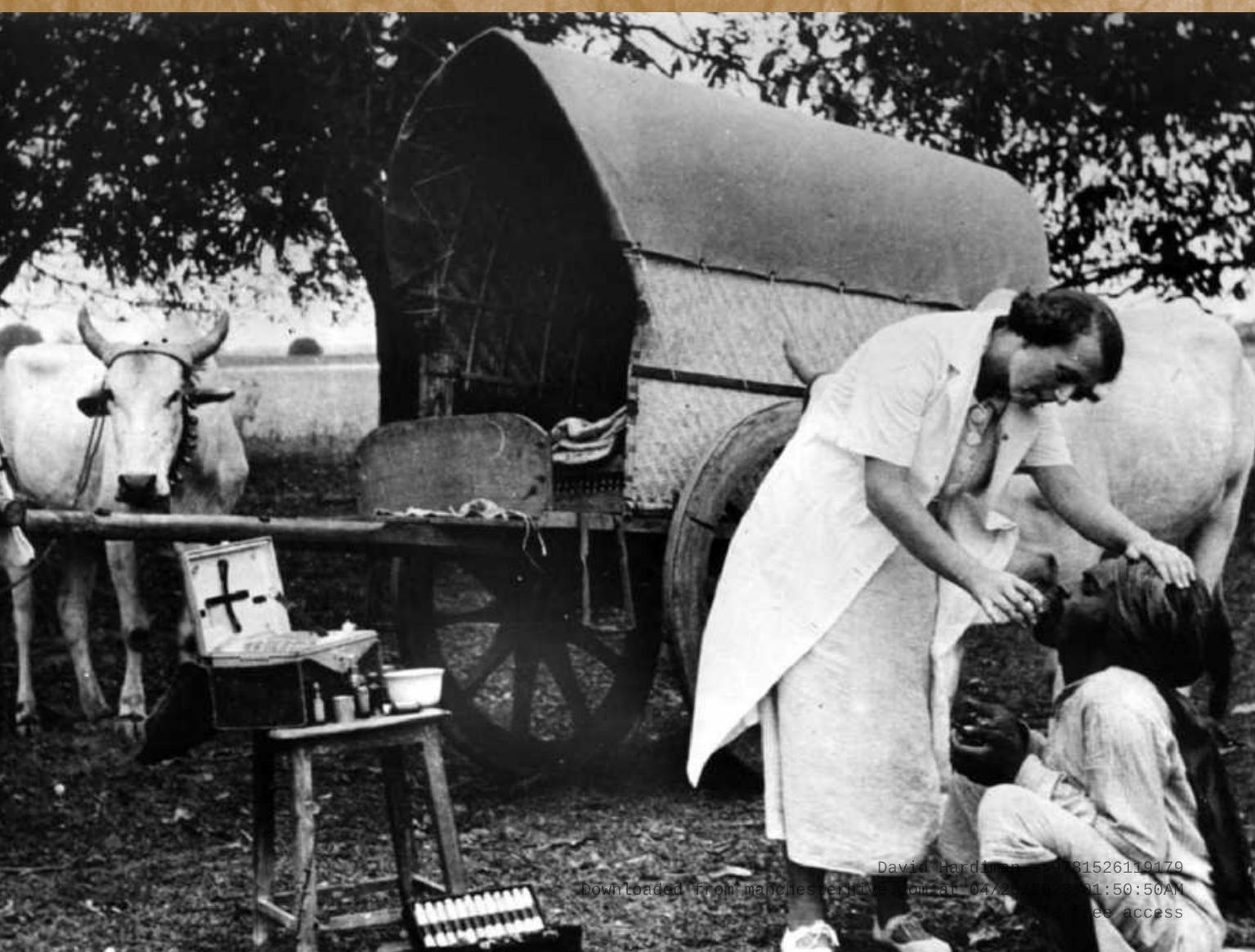




\section{IMPERIALISM}

general editor John M. MacKenzie

When the 'Studies in Imperialism' series was founded more than twenty years ago, emphasis was laid upon the conviction that 'imperialism as a cultural phenomenon had as significant an effect on the dominant as on the subordinate societies'. With more than sixty books published, this remains the prime concern of the series. Cross-disciplinary work has indeed appeared covering the full spectrum of cultural phenomena, as well as examining aspects of gender and sex, frontiers and law, science and the environment, language and literature, migration and patriotic societies, and much else. Moreover, the series has always wished to present comparative work on European and American imperialism, and particularly welcomes the submission of books in these areas. The fascination with imperialism, in all its aspects, shows no sign of abating, and this series will continue to lead the way in encouraging the widest possible range of studies in the field. 'Studies in Imperialism' is fully organic in its development, always seeking to be at the cutting edge, responding to the latest interests of scholars and the needs of this ever-expanding area of scholarship.

\section{Missionaries and their medicine}

\section{MANCHESTER 1824}

Manchester University Press 


\title{
AVAILABLE IN THE SERIES
}

CULTURAL IDENTITIES AND THE AESTHETICS OF BRITISHNESS ed. Dana Arnold BRITAIN IN CHINA Community, culture and colonialism, 1900-1949 Robert Bickers

\author{
RACE AND EMPIRE
}

Eugenics in colonial Kenya Chloe Campbell

RETHINKING SETTLER COLONIALISM

History and memory in Australia, Canada, Aotearoa New Zealand and South Africa ed. Annie E. Coombes

IMPERIAL CITIES

Landscape, display and identity

eds Felix Driver and David Gilbert

IMPERIAL CITIZENSHIP

Empire and the question of belonging Daniel Gorman

SCOTLAND, THE CARIBBEAN AND THE ATLANTIC WORLD, 1750-1820

Douglas J. Hamilton

FLAGSHIPS OF IMPERIALISM

The PやO company and the politics of empire from its origins to 1867 Freda Harcourt EMIGRANT HOMECOMINGS

The return movement of emigrants, 1600-2000 Marjory Harper

ENGENDERING WHITENESS

White women and colonialism in Barbados and North Carolina, 1625-1865 Cecily Jones

REPORTING THE RAJ

The British press and India, c. 1880-1922 Chandrika Kaul

SILK AND EMPIRE Brenda M. King

COLONIAL CONNECTIONS, 1815-45

Patronage, the information revolution and colonial government Zoë Laidlaw PROPAGANDA AND EMPIRE

The manipulation of British public opinion, 1880-1960 John M. MacKenzie

THE SCOTS IN SOUTH AFRICA

Ethnicity, identity, gender and race, 1772-1914 John M. MacKenzie with Nigel R. Dalziel

THE OTHER EMPIRE

Metropolis, India and progress in the colonial imagination John Marriott

SEX, POLITICS AND EMPIRE

A postcolonial geography Richard Phillips

IMPERIAL PERSUADERS

Images of Africa and Asia in British advertising Anandi Ramamurthy

GENDER, CRIME AND EMPIRE Kirsty Reid

THE HAREM, SLAVERY AND BRITISH IMPERIAL CULTURE

Anglo-Muslim relations, 1870-1900 Diane Robinson-Dunn

WEST INDIAN INTELLECTUALS IN BRITAIN ed. Bill Schwarz

MIGRANT RACES

Empire, identity and K. S. Ranjitsinhii Satadru Sen

AT THE END OF THE LINE

Colonial policing and the imperial endgame 1945-80 Georgina Sinclair

THE VICTORIAN SOLDIER IN AFRICA Edward M. Spiers

MARTIAL RACES AND MASCULINITY IN THE BRITISH ARMY, 1857-1914

Heather Streets

THE FRENCH EMPIRE BETWEEN THE WARS

Imperialism, politics and society Martin Thomas

ORDERING AFRICA eds Helen Tilley with Robert J. Gordon

BRITISH CULTURE AND THE END OF EMPIRE ed. Stuart Ward 


\section{Missionaries and their medicine}

A Christian modernity for tribal India

David Hardiman 
Copyright (C) David Hardiman 2008

The right of David Hardiman to be identified as the author of this work has been asserted by him in accordance with the Copyright, Designs and Patents Act 1988.

Published by MANCHESTER UNIVERSITY PRESS

ALTRINCHAM STREET, MANCHESTER M1 7JA, UK

www.manchesteruniversitypress.co.uk

British Library Cataloguing-in-Publication Data

A catalogue record for this book is available from the British Library

Library of Congress Cataloging-in-Publication Data applied for

ISBN 9780719078026 hardback

First published 2008

$\begin{array}{llllllllll}17 & 16 & 15 & 14 & 13 & 12 & 11 & 10 & 09 & 08\end{array}$

10987765543321

The publisher has no responsibility for the persistence or accuracy of URLs for any external or third-party internet websites referred to in this book, and does not guarantee that any content on such websites is, or will remain, accurate or appropriate.

Typeset in Trump Medieval

by Servis Filmsetting Ltd, Stockport, Cheshire 